\title{
Meanings Assigned to the School: Integrative Review of National Literature
}

\author{
Taimara Foresti ${ }^{1, *}$ (D, Israel Kujawa ${ }^{2}$ (D, \& Naiana Dapieve Patias ${ }^{3}$ (b \\ ${ }^{1}$ Universidade Federal de Santa Catarina, Florianópolis, SC, Brasil \\ ${ }^{2}$ Faculdade Meridional, Passo Fundo, RS, Brasil \\ ${ }^{3}$ Universidade Federal de Santa Maria, Santa Maria, RS, Brasil
}

\begin{abstract}
This paper aims to understand the meanings that students, parents, and teachers, assigned to the school, through an integrative review of the last ten years of Brazilian literature (2007-2017). The search in the databases included material from BVS-Psi, SciELO, and PePSIC, using the following terms in both English and Portuguese: meaning AND school; perception AND school; "social representation" AND school. Considering the inclusion and exclusion criteria, 11 papers were selected. The meanings were classified into two categories: (a) Meanings that strengthen the bonds and (b) Meanings that weaken the bonds. Results indicate that the school is represented in several ways, and the research are predominantly conducted with students.
\end{abstract}

KEYWORDS: students, school, review, meanings

\section{Significados Atribuídos à Escola: Revisão Integrativa da Literatura Nacional}

\begin{abstract}
RESUMO - Este artigo tem como objetivo compreender quais são os significados que alunos, pais e professores atribuem à escola, por meio de uma revisão integrativa da literatura brasileira dos últimos dez anos (2007-2017). A busca foi realizada nas bases de dados BVS-Psi, SciELO e PePSIC a partir dos termos em inglês: meaning AND school; perception AND school; "social representation" AND school e em português. Após critérios de inclusão e exclusão, foram selecionados 11 artigos. A análise foi categorizada a partir de duas categorias: (a) Significados que fortalecem os vínculos e (b) Significados que fragilizam os vínculos. Os resultados mostraram que a escola é representada de diversas formas, sendo a maior parte das pesquisas realizadas com os alunos.
\end{abstract}

PALAVRAS-CHAVE: alunos, escola, revisão, significados

The school is an institution that, along with the family, shares the task of preparing and address children and adolescents to society. The school must contribute to the psychological development of students, teachers, family members, and managers. The school can be recognized as part of a group, or a generation, an institutional context with shared meanings which affect the personal identity of all these actors. Beyond these actors, the local community and society as a whole are also school members, and that is why the meanings, perceptions, and representations assigned to the school tend to be diverse (Campolina \& Oliveira, 2009).
The meanings are created to belong to a communicative space, a culture; believing that in this space or culture other people will share such meanings (Angelo \& Lins, 2017). The place of the school in the students, parents and teachers' lives should be better understood, because the high evasion rates show an alarming reality, highlighting the need for interventions to rescue the meaning of school in these people's lives.

Updated information by the National Institute for Educational Studies and Research Anísio Teixeira (INEP) in June of 2017 reveals that $12.9 \%$ and $12.7 \%$ of students

*E-mail: taiforesti@gmail.com

- Submetido: 19/03/2018; Revisado: 30/08/2019; Aceito: 04/09/2019. 
registered in the 1st and 2nd grades of high school, respectively, gave up school between 2014 and 2015, in Brazil. The 9th grade of the elementary school reached the third-highest evasion rate, 7.7\%, followed by the 3rd high school grade, with $6.8 \%$. Considering all grades of high school, evasion reached $11.2 \%$ of the total students in this education phase (INEP, 2017).

School failure and dropout are challenging situations that happen in the school that must be addressed by education and public policy. Evasion and dropout are different situations, which should be explained for a proper understanding of school failure. Evasion can be understood as an escape to perform another activity, i.e. the student leaves the school and no longer returns to that specific environment (Silva \& Araújo, 2017). A school dropout, in turn, happens when the student leaves the school environment, but returns later (INEP, 2017). Evasion and dropout result in a social problem because of the implications for society as a whole. Therefore, the factors which contribute to the incidence and maintenance of these problems in the school environment must be identified and confronted so that more and more teenagers conclude basic education (Auriglietti \& SchmidlinLöhr, 2014).

For a while, school failure was blamed almost exclusively on the student. However, institutional factors and educational practices are known to contribute to this reality, such as class councils, which allow students with low learning rates to move forward without actually learning. Although there is no consensus on the definition of school failure, it has been understood from age / grade distortion, failure, dropout and learning disabilities (Pezzi \& Marin, 2017). However, aspects such as the teacher's role, curriculum, school management, and teacher-student relationship are intervening factors of school failure and need to be reevaluated to prevent the evasion (Forgiarini \& Silva, 2008).

When school failure happens, the relationship between family and school may become conflicting. Parents' expectations and beliefs interfere with understanding the role of the school. They can blame the school for their children's difficulties and behavior, and hold the institution accountable for the students' professional future and sometimes to education as a whole. Parental representations are opposite to the school's narrative, which assigns the difficulties exclusively to the student. The school does not perform effective actions to approach the reality of the students and their parents, and just demand complementarity in the children's education (Saraiva \& Wagner, 2013). The representations of the school, created by the actors (parents, students, teachers, managers, staff), are present in the understanding of the problems in the school education system. When these representations are mistaken, especially concerning poor student performance, they may undermine interest in the school. Besides, successive failures and evasions may lead to school dropout (Nunes et al., 2014).

The consequences of evasion in the student's life are many. The process of accountability for life in society, in the personal and professional perspective, and the context of citizenship can be damaged, as well as the awareness of the rights and duties in society. Another consequence is the restriction or barrier to access positions that require education level. Both evasion and dropout represent the difficulties of continuity and permanence of children and teenagers in school, and the accomplish of basic education (Pezzi \& Marin, 2017).

One way of doing this work, preventively, is by understanding which is the meaning and the representation of the school that parents, students, and teachers have. A reflective look at the representations of freedom, authority, teaching, learning, transmission, and construction (Freire, 1996) allows comprehension of what are the elements that strengthen or weaken the process of attachment between the school main actors. Therefore, this study aimed to understand the meanings that students, parents, and teachers assign to the School, through an integrative review of the national literature.

\section{METHOD}

The method applied was the integrative literature review. This is a specific method that summarizes the past of empirical or theoretical literature to provide a broader understanding of a particular phenomenon, enabling both a summary of studies already published and the search for new knowledge (Botelho et al., 2011).

\section{Search Strategy}

The search for articles in the databases and the analysis of those that were selected took place on December 2017. The databases accessed were: Virtual Health Library Psychology Brazil (BVS-Psi), Scientific Electronic Library Online (SciELO) and Electronic Journals in Psychology (PEPSIC). English descriptors with the Boolean operator
AND were used to search for the studies: meaning AND school, perception AND school, "social representation" AND school; and the same terms in Portuguese. These descriptors were used to access studies that brought different meanings assigned to the school, from different motivations, perceptions, and interpretations. Also, they were included to understand if these attributions are related to the consolidation and breaking of bonds between students and school, and how this happens. The terms parents, students and teachers were not included in the study to not restrict the search. The descriptors were chosen to answer the question "what are the meanings/representations of the school for parents, teachers, and students?"

After searching each database, the following inclusion criteria were used: scientific article; available online; 
open-access; publications in Brazil; from the last 10 years (2007 to 2017); articles that address the theme: meanings or representations assigned to the school by students, parents or teachers. The exclusion criteria were dissertations and/ or theses; books; non-open access articles, studies that did not address the main theme. All duplicate articles were excluded. The abstracts from the pre-selected articles were read, which helped to include or exclude them in this study, seeking greater validity of the searching method.

\section{Study Selection}

The first step was to identify the studies. After applying the inclusion criteria, duplicate publications were discarded based on their titles. Then the researchers read the abstracts and excluded those that did not have the theme as their main objective. Finally, for eligibility, the studies were read in full and the exclusion criteria were applied.

\section{Information Collect Process}

The studies that met the inclusion criteria were analyzed descriptively and qualitatively, in chart form (Chart 1), according to the following selected categories: (a) year of publication and authors, (b) objectives, (c) design, (d) instruments and (e) participants. Chart 2 presents the main results from the articles analyzed regarding the meanings assigned to the school.

\section{Risk of Bias Between Studies}

The search was performed by two independent judges, trying to obtain greater information reliability (Pasquali, 2010). When divergence happens, a third reviewer must be consulted (Zoltowski et al., 2014). In this study, there was a consensus between the two judges, so it was not the necessary intervention of a third judge.

\section{RESULTS}

The initial search showed 3,817 publications in October 2017. Applying the inclusion and exclusion criteria, 38 articles were selected. After reading the abstracts, 20 were excluded, and seven were duplicated. In the end, eleven studies met the grounded criteria and the purpose of this study (Figure 1).

The integrative literature review surveyed the years of publications, study objectives, design, instruments applied and participants. The results are presented in Chart 1.

In general, the objectives of the selected studies were: (1) to present the process of recovering school, the reasons for this return and the meanings of school in adulthood (Ramos \& Stella [E10], 2016); (2) to understand the meaning of school and schooling in different social classes (Passos \& Gomes [E6], 2012); (3) to investigate the meaning assigned to the school by students and parents (Marques \& Castanho [E5], 2011; Lima et al. [E2], 2008); (4) by young people diagnosed with ADHD (Rangel \& Loos [E4], 2011); (5) by young people in psychosocial risk and social vulnerability situations (Matos et al. [E1], 2008; Leite et al. [E9], 2016), besides presenting the relationship between meaning, object, legitimacy and semantic spaces (Angelo \& Lins [E11], 2017); (6) to understand the meaning of school experiences and the relationship with students' life projects (Klein \& Arantes [E8], 2016); 7) to analyze school as a cultural context and existential support for young people (Campolina \& Oliveira [E3], 2009; Brenner \& Carrano [E7], 2014).

Therefore, the objectives of the studies highlighted the perception of students regarding school. Only one study [E2] discussed the parents' representations regarding school, and another one the family and schooling issues [E6]. These findings guide to the need to conduct studies that analyze the meanings of school for parents, students, and teachers simultaneously.

Most of the studies found was a qualitative study (10). This methodological model seems appropriate to study this main theme, because it allows the analysis of perceptions and representations [E9], and can be considered significant methodological support since the structuring of knowledge is always a constructive-interpretative production (Rey, 2002). On the other hand, there is a shortage of quantitative studies and/or studies of mixed-method, capable of inferring and correlating variables, such as learning levels and school perceptions, or future expectations concerning the education.

The results also point out that most of the selected articles used individual and group semi-structured interviews, as well as questionnaires and observations field for data collection. Considering that they are mostly qualitative research, these instruments are suitable for the method selected. Besides, nine of the 11 studies were carried out with students or alumni (children, adolescents or adults) and one study was conducted with parents. Only one theoretical study was found. Although there are researches conducted in this context, a large part investigated the students' perception of the school, excluding parents and teachers from the sample.

In this scenario, future studies that present the perception of the three groups in common (parents, students, and teachers) are needed to reveal different meanings and representations of the school context, allowing more specific and effective interventions to keep and reinforce bonds.

Chart 2 presents the main results overview and the meanings assigned to the school in each of the analyzed studies, revealing potential factors of strengthening or weakening of the bonds. 


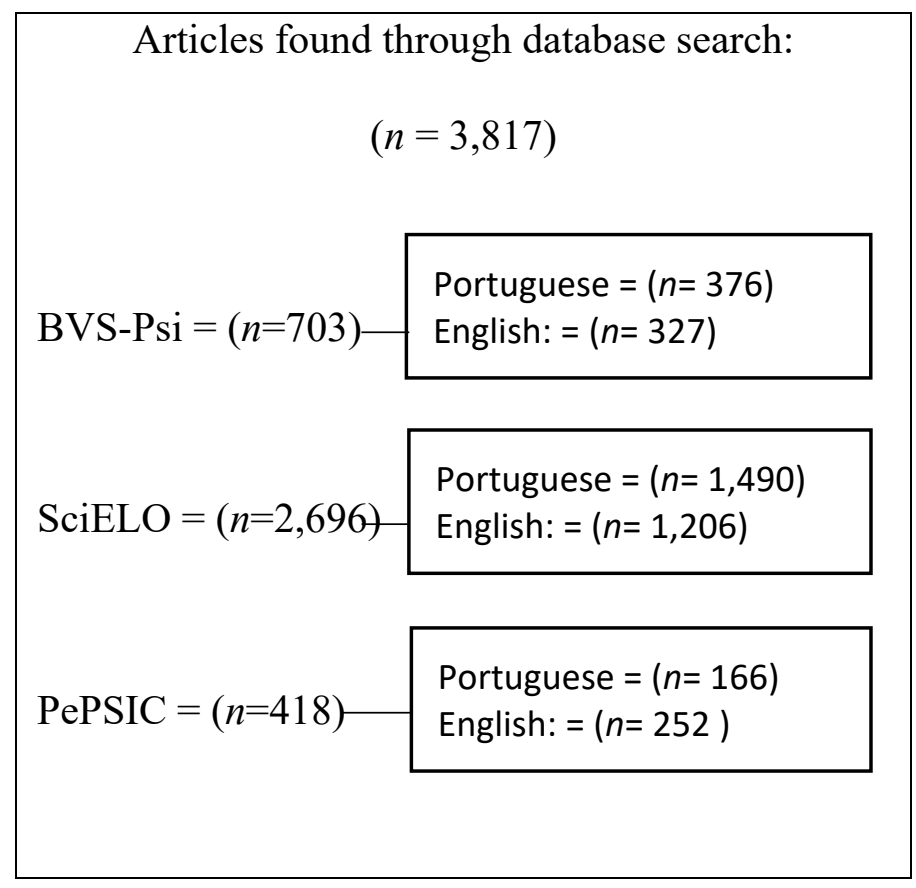

Excluded articles - reasons:

According Inclusion/exclusion criteria $=(n=3,779)$

Duplicate articles $=(n=07)$

Excluded articles after the abstracts reading

$$
(n=20)
$$

Final selection $=11$ articles

Figura 1. Diagram of the flow of selection of the articles

Chart 1

Summary of the analyzed articles

\begin{tabular}{|c|c|c|c|c|c|}
\hline Title & Authors/Year & Objective & Design & Instruments & Participants \\
\hline $\begin{array}{l}\text { The school and the } \\
\text { educational perspectives } \\
\text { of at-risk situations (E1) }\end{array}$ & $\begin{array}{l}\text { Amparo et al. } \\
(2008)\end{array}$ & $\begin{array}{l}\text { To Identify youths in a situation } \\
\text { of psychosocial risk, their school } \\
\text { achievement and aspiration, and } \\
\text { their social support network } \\
\text { related to their teaching-learning } \\
\text { context }\end{array}$ & Quantitative & $\begin{array}{l}\text { Questionnaire } \\
\text { consisting of } 109 \\
\text { multiple choice } \\
\text { questions }\end{array}$ & $\begin{array}{l}852 \text { young people } \\
\text { aged between } 13 \\
\text { and } 27 \text { years old, } \\
\text { attending public high } \\
\text { school }\end{array}$ \\
\hline
\end{tabular}




\begin{tabular}{|c|c|c|c|c|c|}
\hline Title & Authors/Year & Objective & Design & Instruments & Participants \\
\hline $\begin{array}{l}\text { Quality and yearning } \\
\text { for the past: social } \\
\text { representations of } \\
\text { parents about school } \\
\text { (E2) }\end{array}$ & $\begin{array}{l}\text { Lima et al. } \\
(2008)\end{array}$ & $\begin{array}{l}\text { To study the social representations } \\
\text { of students' parents about school }\end{array}$ & Qualitative & $\begin{array}{l}\text { Drawing } \\
\text { Questionnaire } \\
\text { (QD) and Written } \\
\text { Questionnaire (QE). }\end{array}$ & $\begin{array}{l}12 \text { parents, who } \\
\text { attended the same } \\
\text { school as their } \\
\text { children currently } \\
\text { study }\end{array}$ \\
\hline $\begin{array}{l}\text { School culture and social } \\
\text { practices: daily episodes } \\
\text { of school life and the } \\
\text { transition to adolescence } \\
\text { (E3) }\end{array}$ & $\begin{array}{l}\text { Campolina } \\
\& \text { Oliveira } \\
\text { (2009) }\end{array}$ & $\begin{array}{l}\text { To Investigate the school as a } \\
\text { cultural context and analyze } \\
\text { spontaneous interactions between } \\
\text { students, understanding how } \\
\text { the school contributes to outline } \\
\text { the transition from childhood to } \\
\text { adolescence. }\end{array}$ & Qualitative & $\begin{array}{l}\text { School daily } \\
\text { observation sessions } \\
\text { and individual } \\
\text { interviews }\end{array}$ & $\begin{array}{l}12 \text { boys and girls, } \\
\text { attending fifth } \\
\text { and sixth grade of } \\
\text { elementary school }\end{array}$ \\
\hline $\begin{array}{l}\text { Schools and } \\
\text { psychosocial } \\
\text { development according } \\
\text { to the perceptions of } \\
\text { young individuals with } \\
\text { ADHD (E4) }\end{array}$ & $\begin{array}{l}\text { Rangel \& } \\
\text { Loos }(2011)\end{array}$ & $\begin{array}{l}\text { To investigate the perceptions of } \\
\text { adolescents and young adults with } \\
\text { ADHD diagnosis regarding the } \\
\text { school's role in their psychosocial } \\
\text { development, with an emphasis to } \\
\text { identity aspects }\end{array}$ & Qualitative & $\begin{array}{l}\text { Semi-structured } \\
\text { interview }\end{array}$ & $\begin{array}{l}21 \text { former and current } \\
\text { students, } 14 \text { to } 33 \\
\text { years old, diagnosed } \\
\text { with ADHD }\end{array}$ \\
\hline $\begin{array}{l}\text { The school from } \\
\text { students' point-of-view } \\
\text { (E5) }\end{array}$ & $\begin{array}{l}\text { Marques \& } \\
\text { Castanho } \\
(2011)\end{array}$ & $\begin{array}{l}\text { This research fits in the School } \\
\text { and Educational Psychology } \\
\text { field and investigate the meaning } \\
\text { attributed to school by students. }\end{array}$ & Qualitative & $\begin{array}{l}\text { Field observations } \\
\text { and individual and } \\
\text { group interviews, } \\
\text { drawings, collages, } \\
\text { incomplete sentences } \\
\text { and questionnaires }\end{array}$ & $\begin{array}{l}23 \text { children ( } 12 \text { girls } \\
\text { and } 11 \text { boys), ten and } \\
13 \text { years old, from } \\
\text { elementary school }\end{array}$ \\
\hline $\begin{array}{l}\text { Our schools are not } \\
\text { yours: class differences } \\
\text { (E6) }\end{array}$ & $\begin{array}{l}\text { Passos \& } \\
\text { Gomes (2012) }\end{array}$ & $\begin{array}{l}\text { To codify studies and research } \\
\text { concerning the relationship } \\
\text { between educational systems and } \\
\text { social classes, taking the work of } \\
\text { Pierre Bourdieu as its reference }\end{array}$ & $\begin{array}{l}\text { Literature } \\
\text { Review }\end{array}$ & - & - \\
\hline $\begin{array}{l}\text { The senses of the } \\
\text { presence of young } \\
\text { people in High School: } \\
\text { school representations } \\
\text { in three student-made } \\
\text { films (E7) }\end{array}$ & $\begin{array}{l}\text { Brenner \& } \\
\text { Carrano } \\
(2014) .\end{array}$ & $\begin{array}{l}\text { To discuss the challenges facing } \\
\text { education policies and the place } \\
\text { of school as existential support } \\
\text { for young people, based on their } \\
\text { productions (films) }\end{array}$ & Qualitative & $\begin{array}{l}\text { Documentary: Three } \\
\text { films produced by } \\
\text { high school students }\end{array}$ & $\begin{array}{l}\text { High school students } \\
\text { from public schools in } \\
\text { Rio de Janeiro, Bahia } \\
\text { and São Paulo }\end{array}$ \\
\hline $\begin{array}{l}\text { Life Projects of High } \\
\text { School Young Students } \\
\text { and School (E8) }\end{array}$ & $\begin{array}{l}\text { Klein \& } \\
\text { Arantes (2016) }\end{array}$ & $\begin{array}{l}\text { To identify the perception of } \\
\text { high school students about } \\
\text { the contribution that school } \\
\text { experiences can bring to their life } \\
\text { projects. }\end{array}$ & Qualitative & $\begin{array}{l}\text { Questionnaire } \\
\text { consisting of } 10 \text { open } \\
\text { questions }\end{array}$ & $\begin{array}{l}305 \text { freshman and } \\
\text { sophomore from São } \\
\text { Paulo }\end{array}$ \\
\hline $\begin{array}{l}\text { The School direction: } \\
\text { Conceptions of } \\
\text { adolescent students (E9) }\end{array}$ & $\begin{array}{l}\text { Leite et al. } \\
(2016)\end{array}$ & $\begin{array}{l}\text { to analyze the meaning of school } \\
\text { for adolescents in the context of } \\
\text { social vulnerability. }\end{array}$ & Qualitative & $\begin{array}{l}\text { Questionnaire and } \\
\text { incomplete sentences } \\
\text { game }\end{array}$ & $\begin{array}{l}12 \text { teenagers, } 13 \text { and } \\
15 \text { years old, students } \\
\text { from sixth to ninth } \\
\text { year of public school }\end{array}$ \\
\hline $\begin{array}{l}\text { Meaning of schooling } \\
\text { of students of youth and } \\
\text { adult education (E10) }\end{array}$ & $\begin{array}{l}\text { Ramos \& } \\
\text { Stella (2016). }\end{array}$ & $\begin{array}{l}\text { To present the investigation of the } \\
\text { process of return to adults' school, } \\
\text { the reasons for the return and the } \\
\text { meanings of school in adulthood. }\end{array}$ & Qualitative & $\begin{array}{l}\text { Interviews and life } \\
\text { story }\end{array}$ & $\begin{array}{l}\text { Six young adults, } \\
\text { elementary school } \\
\text { students }\end{array}$ \\
\hline $\begin{array}{l}\text { Students talk about } \\
\text { school: from the adults' } \\
\text { world to Neverland } \\
\text { (E11) }\end{array}$ & $\begin{array}{l}\text { Angelo \& Lins } \\
(2017)\end{array}$ & $\begin{array}{l}\text { To evidence the meanings of } \\
\text { school assigned by students } \\
\text { based in notions of meaning, } \\
\text { object, legitimateness and } \\
\text { communicative space }\end{array}$ & Qualitative & $\begin{array}{l}\text { Semi-structured } \\
\text { interview }\end{array}$ & $\begin{array}{l}18 \text { students' speeches } \\
\text { attending final years } \\
\text { of elementary local } \\
\text { School. }\end{array}$ \\
\hline
\end{tabular}


Chart 2

Summary and overview of the meanings assigned to the school

\begin{tabular}{|c|c|c|}
\hline Studies & Overview & Meanings assigned to the school \\
\hline (E1) & $\begin{array}{l}\text { Youth educational perspectives on attendance, expulsion, and } \\
\text { failure were verified } \\
\text { - } 95.4 \% \text { of students attend school daily } \\
\text { - } 6 \% \text { have difficulties being in school } \\
\text { - } 1.9 \% \text { have already been expelled } \\
\text { - } 43.3 \% \text { failed. Most failed only once }(57.73 \%), 30.7 \% \text { failed } \\
\text { twice, and } 11.54 \% \text { three or more times. } \\
\text { - } 90.7 \% \text { of students agree that studies are important today, } 3.1 \% \\
\text { disagreed and } 6.2 \% \text { remained neutral } \\
\text { - Influence of studies x future: } 94 \% \text { reported the importance of } \\
\text { studies } \\
\text { - } 86.5 \% \text { answered that the family strongly encourages studies } \\
\text { - Teacher's role = worrying, few students say they can trust } \\
\text { ( } 37.7 \% \text { ) or count }(40.5 \%) \text { on teachers. }\end{array}$ & $\begin{array}{l}\text { - Family and school are key contexts and youth support networks } \\
\text { - Participants trust friends, teachers and school structure (although } \\
\text { there is a contradiction) } \\
\text { - Most students like the school environment and want to stay in } \\
\text { school } \\
\text { - To investigate the role of teachers is important, because they are } \\
\text { part of the most effective support and protection network in the } \\
\text { school context } \\
\text { - Affective relationships of friendship are important } \\
\text { - School is seen as a provider of these relationships } \\
\text { - The school helps reduce risk factors and develop social skills } \\
\text { - School's role is to encourage positive characteristics }\end{array}$ \\
\hline (E2) & $\begin{array}{l}\text { - The interpretation of the results was based on the representation } \\
\text { that the students' parents have of the school. } \\
\text { - "School: Overview" (drawing analysis) } \\
\text { - "School: Socialization Space (subdivided into title analysis and } \\
\text { narrative analysis)" } \\
\text { - "School: Struggles, Coping, and Achievements" (the analysis of } \\
\text { the answers to these specific questions) } \\
\text { - The school was represented as facilitating positive conditions to } \\
\text { personal/professional life } \\
\text { - Emphasis on interpersonal relationships (discipline and moral) } \\
\text { - School as an access route to professional, social and economic } \\
\text { progress } \\
\text { - Parents have a more conservative view of the school }\end{array}$ & $\begin{array}{l}\text { - School represented as a social space that allowed to reinforce } \\
\text { friendships and values } \\
\text { - School perceived as a place of value and "morality" (rules, } \\
\text { norms, order) } \\
\text { - The school is seen not only as a space for the acquisition } \\
\text { of knowledge but as a place that allows the construction of } \\
\text { meaningful friendship bonds } \\
\text { - Nuclear representation as "good quality school" } \\
\text { - School as a fundamental institution for children's learning and to } \\
\text { socially advance }\end{array}$ \\
\hline (E3) & $\begin{array}{l}\text { - The analysis of the illustrative episode demonstrates two } \\
\text { constitutive dimensions of the adolescent subjectivity meanings } \\
\text { in the school context } \\
\text { - (1) the moralizing role played by the school in the course of } \\
\text { development: corporal punishment was eliminated with the } \\
\text { emergence of humanistic pedagogies } \\
\text { - (2) the adolescent's own experience can play a transformative } \\
\text { role, re-signifying school norms: school context x wider } \\
\text { context of society = contribution to the construction of students' } \\
\text { subjectivity }\end{array}$ & $\begin{array}{l}\text { - The school cannot be considered a neutral space } \\
\text { - Adult-centered logic leads school to push children toward } \\
\text { adolescence and adulthood } \\
\text { - School curriculum and daily life should highlight the unique } \\
\text { experiences of students and teachers. } \\
\text { - The teacher, a central role in this process, deserves special } \\
\text { attention, since he/she is in constant transformation, along with } \\
\text { the students and the school context }\end{array}$ \\
\hline (E4) & $\begin{array}{l}\text { - A large number of failures }(48 \%) \text {, expulsions }(19 \%) \text { and } \\
\text { compulsory transfers }(28 \%) \text { were found } \\
\text { - Individuals with ADHD tend to have difficulty adjusting to the } \\
\text { school system } \\
\text { - Reasons of why Parents were called to school: indiscipline, poor } \\
\text { grades, inattention } \\
\text { - Students were characterized, mainly by teachers, with prejudiced } \\
\text { adjectives } \\
\text { - In general, there is a positive relationship between school and life } \\
\text { projects. }\end{array}$ & $\begin{array}{l}\text { - The school was identified as quite difficult, often even hostile } \\
\text { - Half of the study participants reported negative school-related } \\
\text { feelings } \\
\text { - Some of them showed sorrow for school } \\
\text { - The school revealed, in this study, low effectiveness with } \\
\text { "regular" and "special" students. }\end{array}$ \\
\hline (E5) & $\begin{array}{l}\text { - School is a promise of a worthy future, but it is daily lived } \\
\text { unsatisfactorily, offering inaccurate and meaningless lessons, } \\
\text { disrespectful interpersonal relationships. Perceptions of public } \\
\text { indifference and tiredness of students and teachers were also } \\
\text { reported }\end{array}$ & $\begin{array}{l}\text { - School is perceived as necessary and available for students to } \\
\text { learn, to get a job and be someone } \\
\text { - Perception of "saving school" } \\
\text { - There are many negative meanings assigned to school such as } \\
\text { "school that has no purpose" }\end{array}$ \\
\hline
\end{tabular}


- First, the study shows how the education system operates in a class society, where there is an unequal distribution

- Second, the study shows how different classes relate themselves with the education system

- The education system maintains a class distinction when treating the unequal equally

- The appropriation of the contents and the success in the school trajectory depend on the cultural heritage of each one.

(E6)

- Popular-class families, unlike common sense, want that their children have a different future

- For middle-class families school is a step to achieve better jobs and a higher salary

- School achievement is relative in the upper classes (above average failures and approvals), but has the tools to reverse negative outcomes

- Students use audiovisual devices to narrate their school experiences and their desire to have better schools

- The three films chosen came from a national festival exhibited on the internet called IMAGENS, from Portal Ensino Médio EM Diálogo, whose theme was "A school without walls" in 2014

- 1st movie: +30 , portray a school with security cameras, windows and corridor bars, safety nets and padlocks, where violence, prejudice, and discrimination are always present. There is criticism regarding the More Education program

- The 2nd movie "My home, schools without walls" describe the school as simple but full of color. The school in this movie is portrayed very positively. The school is a place to belong with, a shelter, a family that welcomes and helps to cope with difficult moments in each student's trajectory

- In the 3rd movie, "A Learning Dream," the representation of good teaching that leads to higher performance identifies with the story and with the situations that happened outdoors, showing the importance of interacting with each student's context

- Categories were created from the questions and answers of the students

- The school is represented as a place that prepares for the future, social relationships and work market

- Classroom experiences are very important in the students' schooling process

- Students reported that the link between lectures content and their life projects is fragile

- There is difficulty in connecting what students learn at school with everyday life

- Students perceive that the school is orientated to the work market

- Learning politics it is not enough because it is essential to know how to live in a society

- The place occupied by students is still primarily the classroom, and what students experience is important to their life projects
- The school and its products, knowledge, and degrees do not have the same meaning for all social classes, not even for groups that are part of these classes

- This meaning depends on their position in the social context, that is, on their properties

- The three films reveled criticism about the meanings of school and about the students' wishes about what the school could be

- Firstly, the school was represented as a precarious place, inside bars and walls, forbidding the student's subjectivity through a depersonalization mechanism

- The school was later represented as a shelter from the storms, and support for future projects

- Finally, the school was perceived as a dream. a place that could dialogue with the world, because knowledge does not fit only within the classroom and into thirty questions' test

- The information collected reassure the discourse associated with the school's function in a perspective of 'becoming'

- The lectures follow a logical order that aims the promotion of knowledge, hiding the relation discipline versus daily life.

- The school must have a formative role - citizenship versus school

- Students lived significant experiences in school

- School appreciate students when they assign meaning in teaching

- Activities that favor student protagonism (participation in cultural animation projects and activities) are important for an education that aims the development of autonomy, responsibility, and commitment through collective interests 


Studies Overview Meanings assigned to the school

- The study was divided into four categories: 1) Characteristics of the vulnerability context; 2 ) adolescents' perception of the school; 3) how the school deals with adolescents; 4) expectations of adolescents regarding school

- In category 1) the participants that failure said that they were reproved by the school management or the technical staff

- They have little access to health and leisure conditions, and where they live violence is frequent

- In category 2) all participants characterized the school as a place to study and learn

- The school as a space that protects against violence and promotes friendships

- Good teachers establish dialogue and relationship with students

- Bad teachers are insensible and do not dialogue or interact with students in the classroom

- In category 3) one student reported feeling like an immature teenager

- Two students reported being treated as children, receiving advice and help

- One teenager reported being treated with indifference because she could not ask questions

- Another student as a bad person, due to the teachers talking about where he lived

- Students would like to be treated as "good citizens", with respect and as "real people"

- In category 4) students had expectations of having a good future with a profession and a good job

- Some people difficulty or lack of access to education refers to the discrimination and inequality of the historical process in Brazil

- Students return to school searching for a chance of professional improvement

(E10)

- Education perspective as a form of social recognition. "Only through education is it possible to do something profitable"

- When young adult education (EJA) students acquire knowledge at school, they recognize themselves as human rights subjects

- Students answered the question "How would you explain what school is to someone who knows nothing about it?". Some of the answers were: "Place where we study, learn, have classes and education"

- "Place where we learn things we will need in the future"

- "Place to get a good job, have a better life, be someone in life"

- "Place of fun, socializing, making friends"

(E11) - "Place to acquire knowledge, where young people learn to live together and receive education beyond that provided by the family"

- "The school enables young people to have a better life in the future"

- Students indicated that socializing with friends, games, and fun were the things they liked most. All of this occupied a much more relevant status than learning the school content
- Participants highlight the meanings of the school

- Adolescents perceive school as an important institution, capable of contributing to their formation and enabling, through study, social progress, and decent and qualified jobs.

- Students identify the failures of the school by guaranteeing the right to quality education: unsatisfactory dynamics of some classes, an inadequate attitude of some professionals, lack of opportunities to express and participate in decision making, content not connected to reality, teachers who do not establish a pleasant relationship with students and sometimes disrespect them.

- Students also consider the school as a place to meet and to keep affective bonds

- The most important and noted aspects reported by the students focus on the good relationship established with others, friendships, moments of relaxation and fun and the school spaces that provide these situations

- The school teaching methods are incompatible with the student's daily experiences

- Students feel unmotivated because the school offers something uninteresting

- Student failure is regularly attributed to the own student, to the culture of where he/she lives, regardless of school teaching methods

- There is an idea that permeates the relationship established between school and work: the longer the years of education, the greater the possibilities of work and therefore the better positions

- The possibility of ascending to a better position, if any, is for the minority

- The same work market that took children out of school to help support their families now requires that the worker adult return to the school classroom

- School as a place where students receive education and knowledge, and live with different people, allowing them to have a better life in the future, a goal

- When the students saw themselves as part of the school, it took on another meaning - a place of fun, conversations, meeting with friends - different from that assigned by the teachers

$\mathrm{E}=$ study; E1=study $1 ; \mathrm{E} 2=$ study 2. 


\section{DISCUSSION}

The results indicated different meanings assigned to the school. Some meanings may contribute to the strengthening of the student's bond with the school. Studies indicate that school can interfere with the development of positive bonds with students producing exclusion, dropout, and evasion.

The selected studies were divided into two broad categories to better understand the analysis and discussion of the results: (a) Meanings that strengthen bonds, emphasizing the positive aspects, and (b) Meanings that weaken bonds - try to understand what can be done to improve specific situations.

The most important aspects that contribute to strengthen the bonds were: assertive communication, consideration for the students' singularity, presence of parents, the teacher's attitude, and appreciation of life context. The highlighted aspects that contribute to weakening the bonds were: uncertainty regarding school, the "meaningless" school, high rates of failure and low motivation, disconnected relations between student, school, and society, and background inequality. The subcategories mentioned were organized by the authors, considering the findings and the prevalence of these themes in the studies.

\section{Meanings that Strengthen the Bonds}

\section{Assertive Communication}

The meanings assigned to the school that strengthen the bonds are related to the school's role. The positive aspects were the flexibility and the school's involvement concerning the communication with parents, thus establishing a positive relationship [E6]. In this context, education goes beyond the physical environment. When it steps in the students' lives, playing an essential role, the school is no longer seen as an institution that only reproduces the dominant ideology (Freire, 1996).

Family-school communication is a fundamental point that needs to be improved. School's speech draws attention to the education of children at home, while the family wants to interact and learn more about their child's daily life at school (Saraiva \& Wagner, 2013). The beliefs and expectations of both contexts regarding student education need to be better understood to make communication more assertive.

\section{Students' Singularity}

The school was also understood as an essential part of students' life projects, as a part of the human formation process, and this influences the meaning that each student assigns to the school [E8]. The school is recognized as a place of socialization and as a source of social and affective support, which promotes resilience and promotes challenging, not threatening experiences [E1]. Another responsibility of the school should be to consider the subjectivity of each student, stimulate self-confidence and cooperate in shaping their personality.

\section{Presence of Parents}

Another important result was the involvement of parents and/or family members in the school setting. In this context, it is unquestionable that the presence of parents can stimulate their children's freedom of decision and responsibility [E2]. Family involvement in the school not only improves student performance, but also the whole family relationship (Saraiva \& Wagner, 2016). The benefits of parental participation increase the relevance of studies and reinforce the positive aspects of the school environment. Parents, in turn, feel more benefited as conflicts with school decrease, and the sense of well-being increases (Cavalcante, 1998).

\section{Teacher Attitude}

The feelings and the sense of well-being in the school environment are, sometimes, left in the background. They can reflect the pleasure of going to school, strengthens student permanence and contributes to reducing evasion. The attitude of teachers can actively favor this process, as they create expectations (positive or negative) in each student and can influence the failure or the success of academic life [E10]. Investing in the continuing education of teachers is also important so that classes can be more dynamic and establish a relationship between the lectures and the experiences lived by students, making dialogue and exchanges in the classroom easy, and result in a sense of permanence in the classroom [E9].

\section{The Appreciation of Life Context}

The necessity to relate the school context with the student's social context has also received an important meaning since the school-society relationship contributes to the construction of student subjectivity [E3]. Therefore, what students learn from their experiences and what they live casually in the school context cannot be neglected, but considered, from the singularity of each student. 


\section{Meanings that Weaken the Bonds}

\section{Uncertainty Regarding School}

The meanings that interfere in strengthening the bonds between students and school are varied but mostly refer to the school's role. An ambivalence of meanings assigned to the role of the school by parents, students and/or teachers can be seen in the studies' results. One of the studies [E2] provides an example of this. The article reports that parents see the school as an institution responsible for tracing the social trajectory of their children, and should offer possibilities for professional, economic and family growth, include them socially. This research adds that failure to meet this expectation generates frustration and difficulty in communication between parents and school. Another aspect described by the studies was the school's difficulty in dealing with student differences. Besides, the construction of a more democratic environment within the school requires a collective effort [E5]. Studying and being at school does not make sense, for some students. On the other way, for other students, a school can be existential support [E7].

\section{The "Meaningless" School}

One study [E5] reveals the speech of some students who indicate the school as something worthless, which serves only to ruin students. This perception of school weakens the bond with students and leads to believe that the only possible solution is a dropout. In this context, it is necessary to strengthen this relationship, helping the school to have a significant value in the students' lives. The activities performed obtain higher significance when they are more than obligations and are related to the student's social life. Education must perpetrate personal knowledge so the learning process achieves meaning and importance (Reis, 2012).

\section{High Rates of Failure and Low Motivation}

Some studies have found high failure rates $(46.9 \%$ [E2] and $48 \%$ [E4]), expulsion (19\% [E4]) and compulsory transfers $(28 \%$ [E4]). These rates may be related to the weakness of the bond between the student and the school, reported by students with some difficulty in school. These individuals also showed negative school-related emotions, revealing hurt feelings about teachers' behavior by giving prejudiced adjectives to some students. Also, they verbalized that parents are called to school only to deal with indiscipline, poor grades and inattention [E4]. The teacher's role takes on a central part because it is no longer just a content communicator and becomes an agent of change in students' lives, cause encourages them to be citizens and to think critically, and to use the contents learned at school in different daily situations (Bulgraen, 2010).

\section{Disconnected Relations Between Student, School, and Society}

The experiences of each student must be respected. The school curriculum and daily life need to consider and respect these unique experiences, and not exclude them. Also, the school needs to understand that it is inside a context that interacts with society, and therefore, it is part of the construction of each student subjectivity [E3]. The school's functioning and routine show how these elements still play an important role in the students' subjective experience [E3]. There is no single institution (school) that fulfills a specific role (transmitting content), that is, the school will always be in dialogue with the society demands that go through socio-historical issues.

\section{Background Inequality}

Finally, one of the studies highlighted the aspects of education in different social classes, where teaching happens unevenly. When the education system treats the different equally, it maintains this distinction, weakening the student-school bond [E6]. This situation also happens when the school follows a "model" and tries to fit all students in it, regardless of their singularities, producing a moralizing discourse and maintaining inequalities. The learning process is also influenced by the school's perception of the family, often naming it as "broken families". The school needs to consider cognitive, social, affective and cultural aspects, and accept that students have prior knowledge from their previous relationships, and is part of a family system that has its own culture (Júnior et al., 2015).

\section{FINAL CONSIDERATIONS}

The results of this research suggest that, in recent years, some studies have investigated the meanings assigned to the school by students. These studies used, predominantly, the qualitative design to understand the phenomenon.

The findings of the studies understand that a school is an indispensable place, which has many positive and negative meanings. The positive meanings listed were: a necessary place to learn, to develop, to exercise autonomy and responsibility, "to have a future and be someone", among others. Negative meanings were also attributed: hostile place, that does not accept differences, that "have no purpose", that plays a moralizing role, among others. Rethinking the meanings of the school context can help to design interventions to strengthen the bonds between school and student, as well as between school and family, to avoid evasion or school failure. 
The steps developed in this field, so far, need to walk beyond the curriculum, and the old school model that should no longer holds today. The school is still recognized, mainly, as an institution that does not effectively interact with students, and is not prepared for diversity and innovation. The school's role must be reconsidered as an institution integrated into a social and political context. This institution has to undertake ethical responsibilities not only for education but for students and teachers. On the other hand, it is necessary for the family to effectively participate in the education process of their children because it seems that they do not know their commitment as a family.

This study has limitations regarding the chosen databases. Future studies may broaden the search on different bases, as well as review international and empirical studies. The authors suggest including other descriptors, such as beliefs and expectations. Future studies should also investigate whether there is a correlation between the meanings assigned to school and variables such as evasion, failure, prejudice and symptoms of mental disorders, for example. Psychology can take a critically reflective position concerning the meaning of school for students, parents, and teachers.

Providing meetings to training and dialogue between the three groups can contribute to the strengthening of bonds, and facilitate the understanding of the teacher's role in the student dropout process. It is necessary to work with all school agents to develop and promote a more critical and changing education, establishing more coherent meanings to the school.

\section{REFERENCES}

Amparo, D. M. do, Galvão, A. C. T., Cardenas, C., \& Koller, S. H. (2008). A escola e as perspectivas educacionais de jovens em situação de risco. Psicologia Escolar e Educacional, 12(1), 69-88. https://doi.org/10.1590/S1413-85572008000100006

Angelo, C. L., \& Lins, R. C. (2017). Alunos falam sobre a escola: do mundo dos adultos à terra do nunca. Educar em Revista, 62, 165-180. https://doi.org/10.1590/0104-4060.44134

Auriglietti, R. C. R., \& SchmidlinLöhr, S. (2014). Evasão escolar: Causas, consequências e alternativas - $\mathrm{O}$ combate à evasão escolar sob a perspectiva dos alunos. Caderno: Os Desafios da Escola Pública Paranaense na Perspectiva do Professor PDE, 01, 1-21. http://www.diaadiaeducacao.pr.gov.br

Botelho, L. L. R., Cunha, C. C. de A., \& Macedo, M. (2011). O método da revisão integrativa nos estudos organizacionais. Gestão $e$ Sociedade, 5(11), 121-136. https://doi.org/10.21171/ges. v5i11.1220

Brenner, A. K., \& Carrano, P. C. R. (2014). Os sentidos da presença dos jovens no ensino médio: Representações da escola três filmes de estudantes. Educação \& Sociedade, 35(129), 2231240. https://doi.org/10.1590/ES0101-73302014143847

Bulgraen, V. C. (2010). O papel do professor e sua mediação nos processos de elaboração do conhecimento. Revista Conteúdo, 1(4), 30-38. http://www.conteudo.org.br/index.php/ conteudo/article/viewFile/46/39

Campolina, L. O., \& Oliveira, M. C. S. L de. (2009). Cultura escolar e práticas sociais: Episódios cotidianos da vida escolar e a transição para a adolescência. Educação e Pesquisa, 35(2), 369-380. https://doi.org/10.1590/S1517-97022009000200010

Cavalcante, R. S. C. (1998). Colaboração entre pais e escola: Educação abrangente. Psicologia Escolar e Educacional, 2(2), 153-160. https://doi.org/10.1590/S1413-85571998000200009

Forgiarini, S. A. B., \& Silva, J. D. (2008). Fracasso escolar no contexto da escola pública: Entre mitos e realidades. Secretaria de Educação do Paraná: Dia a Dia Educação, 1-27. http:// www.diaadiaeducacao.pr.gov.br/portals/pde/arquivos/369-4.pdf

Freire, P. (1996). Pedagogia da Autonomia: Saberes necessários à prática educativa. Paz e Terra.

Instituto Nacional de Estudos e Pesquisas Educacionais Anísio Teixeira. (2017). INEP divulga dados os inéditos sobre o fluxo escolar na educação básica. http://portal.inep.gov.br/artigo/-/ asset_publisher/B4AQV9zFY7Bv/content/inep-divulgadados-ineditos-sobre-fluxo-escolar-na-educacao-basica/21206

Júnior, I. B. O., Moraes, D. A. F. de., \& Coimbra, R. M. (2015). Família "margarina": As estereotipias de famílias na indústria cultural e a des/re/construção de conceitos docentes. Revista HISTEDBR On-line, 15(64), 266-279. https://doi.org/10.20396/ rho.v15i64.8641941

Klein, A. M., \& Arantes, V. A. (2016). Projetos de vida de jovens estudantes do ensino médio e a escola. Educação \& Realidade, 41(1), 135-154. https://doi.org/10.1590/2175623656117

Leite, F. M., Pessoa, M. C. B., Santos, P. dos, Rocha, G. F, \& Alberto, M. P. (2016). O sentido da escola: Concepções de estudantes adolescentes. Psicologia Escolar e Educacional, 20(2), 339348. http://doi.org/10.1590/2175-3539/2015/0202983

Lima, R. D. C. P., Colus, F. A. M., Gonini, F. A. C., Mokwa, V. M. N. F, \& Petrenas, R. D. C. (2008). Qualidade e saudosismo: Representações sociais de pais sobre a escola. Psicologia da Educação, 27, 31-51. http://pepsic.bvsalud.org/scielo. php?script $=$ sci_arttext\&pid=S1414-69752008000200003

Marques, P. B., \& Castanho, M. I. S. (2011). O que é a escola a partir do sentido construído por alunos. Psicologia Escolar e Educacional, 15(1), 23-33. http://doi.org/10.1590/S141385572011000100003

Nunes, T. G. R., Pontes, F. A. R., Silva, L. I. da C, \& Dell'Aglio, D. D., (2014). Fatores de risco e proteção na escola: Reprovação e expectativas de futuro de jovens paraenses. Psicologia Escolar e Educacional, 18(2), 203-210. http://doi.org/10.1590/2175$3539 / 2014 / 0182732$

Passos, G. D. O., \& Gomes, M. B. (2012). Nossas escolas não são as vossas: As diferenças de classe. Educação em Revista, 28(2), 347-376. http://doi.org/10.1590/S0102-46982012000200016

Pasquali, L. (2010). Instrumentação psicológica: Fundamentos e práticas. Artmed.

Ramos, E. T. de, \& Stella, C. (2016). Significados da escolarização para alunos da educação de jovens e adultos. Psicologia: Teoria e Prática, 18(2), 189-207. http://doi.org/10.15348/1980-6906/ psicologia.v18n2p189-207

Rangel, E. de B. Jr., \& Loos, H. (2011). Escola e desenvolvimento psicossocial segundo percepções de jovens com TDAH. Paidéia, 21(50), 373-382. http://doi.org/10.1590/ S0103-863X2011000300010

Reis, R. (2012). Experiência escolar de jovens/alunos do ensino médio: os sentidos atribuídos à escola e aos estudos. Educação e Pesquisa, 38(3), 637-652. http://doi.org/10.1590/S151797022012000300007

Rey, F. G. (2002). Pesquisa qualitativa em Psicologia: Caminhos e desafios. Pioneira Thomson Learning. 
Saraiva, L. A., \& Wagner, A. (2013). A relação família-escola sob a ótica de professores e pais de crianças que frequentam o ensino fundamental. Ensaio: Avaliação e Políticas Públicas em Educação, 21(81), 739-772. http://doi.org/10.1590/S010440362013000400006

Saraiva, L. A., \& Wagner, A. (2016). Os estudos sobre a Relação Família-Escola no Brasil: Uma revisão sistemática. Educação, 39(esp), 114-124. http://doi. org/10.15448/1981-2582.2016.s.21333
Silva, F. R. B., \& Araújo, R. M. de L. (2017). Evasão e abandono escolar na educação básica no Brasil: Fatores, causas e possíveis consequências. Educação Por Escrito, 8(1), 35-48. http://doi.org/10.15448/2179-8435.2017.1.24527

Zoltowski, A. P. C., Costa, A. B., Teixeira, M. A. P, \& Koller, S. H. (2014). Qualidade metodológica das revisões sistemáticas em periódicos de psicologia brasileiros. Psicologia: Teoria e Pesquisa, 30(1), 97-104. https://doi.org/10.1590/S010237722014000100012 